\title{
Early events in living epidermal cells of cowpea and broad bean during infection with basidiospores of the cowpea rust fungus
}

\author{
Haixin Xu AND Kurt Mendgen ${ }^{1}$ \\ Lehrstuhl für Phytopathologie, Fakultät für Biologie, Universität Konstanz, D-7750, Konstanz, Germany
}

Received February 27, 1991

\begin{abstract}
Xu, H., and Mendgen, K. 1991. Early events in living epidermal cells of cowpea and broad bean during infection with basidiospores of the cowpea rust fungus. Can. J. Bot. 69: 2279-2285.

The infection process of basidiospores of the cowpea rust fungus (Uromyces vignae) was studied on living host (Vigna sinensis) and nonhost (Vicia faba) leaves using light microscopy with differential interference contrast optics. During the first $8 \mathrm{~h}$, fungal development was similar on host and on nonhost leaves. Penetration and production of intraepidermal vesicles occurred in nonhost cells $4 \mathrm{~h}$ earlier than in host cells. Penetration frequency was also higher in nonhost leaves. These results suggest that the cuticle of the cowpea plant delays basidiospore infection. Both host and nonhost cells produced cytoplasmic aggregates during appressorium formation and again, a few hours later, during penetration of the epidermal cell wall. Cytoplasmic aggregates were also observed in cells adjacent to a collapsing cell. Papillae were observed at most infection sites in both host and nonhost cells. The nuclei of infected cells migrated towards the penetration site in both plant-pathogen combinations. Nuclear size increased considerably only in the nonhost epidermis and decreased again markedly after cell collapse. In the nonhost cells, three types of defence reactions occurred during or after formation of the intraepidermal vesicle. First, following the halt of cytoplasmic streaming, the cytoplasm of the invaded cell either contracted or disintegrated into granules. Alternatively, the cytoplasm continued streaming but darkly pigmented material encased the fungal infection structure.
\end{abstract}

Key words: basidiospore, broad bean (Vicia faba), cowpea (Vigna sinensis), cowpea rust fungus (Uromyces vignae), hypersensitivity, nonhost resistance.

Xu, H., et Mendgen, K. 1991. Early events in living epidermal cells of cowpea and broad bean during infection with basidiospores of the cowpea rust fungus. Can. J. Bot. $69: 2279-2285$.

En utilisant la microscopie optique équipée en contraste d'interférence différentielle, les auteurs ont étudié le processus d'infection par les basidiospores du champignon de la rouille (Uromyces vignae) chez un hôte (Vigna sinensis) et chez un non-hôte (Vicia faba). Au cours des premières $8 \mathrm{~h}$, le développement fongique est semblable chez les feuilles de l'hôte et celles du non-hôte. La pénétration et la production de vésicules intraépidermiques s'effectue dans les cellules du non-hôte, $4 \mathrm{~h}$ plus tôt que chez les cellules de l'hôte. La fréquence de pénétration est également plus élevée dans les feuilles du nonhôte. Les résultats suggèrent que la cuticule des plants de pois chiches retarde l'infection par les basidiospores. Les cellules de l'hôte et du non-hôte produisent toutes les deux des agrégats cytoplasmiques au cours de la formation de l'appressorium et encore, quelques heures plus tard, pendant la pénétration des parois cellulaires de l'épiderme. On observe également des agrégats cytoplasmiques dans les cellules adjacentes à celles d'une cellule en affaissement, ainsi que des papilles, dans la plupart des sites d'infection, chez les cellules de l'hôte aussi bien que du non-hôte. Les noyaux des cellules infectées migrent vers un point de pénétration, dans le cas des deux systèmes hôte-pathogène. La dimension des noyaux augmente considérablement, mais seulement dans l'épiderme du non-hôte, pour diminuer de nouveau et de façon marquée après l'affaissement de la cellule. Chez les cellules du non-hôte, on retrouve trois types de réactions de défense au cours et après la formation de la vésicule intraépidermique. En premier, suite à l'arrêt du mouvement cytoplasmique, le cytoplasme de la cellule envahie ou bien se contracte ou bien se désintègre en granules. Alternativement, le mouvement cytoplasmique se pursuit, mais du matériel fortement pigmenté encapsule les structures d'infection fongique.

Mots clés : basidiospores, fève (Vicia faba), pois chiches (Vigna sinensis), champignon de la rouille du pois chiche (Uromyces vignae), hypersensibilité, résistance du non-hôte.

[Traduit par la rédaction]

\section{Introduction}

On angiosperms, basidiospores of most rust fungi produce germ tubes with more or less pronounced appressoria and penetration occurs directly through the cuticle and the epidermal cell wall (Gold and Mendgen 1991). After penetration of the cell wall, intraepidermal vesicles and primary hyphae are formed in the epidermal cells (Gold and Mendgen 1984). At this stage of infection the cells of incompatible host plants and nonhost plants react hypersensitively (Freytag 1990; Heath 1989). In these previous studies, however, fixed and cleared material was used and the dynamics of the cytoplasmic movement could not be followed during infection. Therefore, a method was developed to study the infection process of basidiospores and the reactions of living infected cells by light

\footnotetext{
${ }^{1}$ Author to whom all correspondence should be addressed.
}

microscopy. The present study attempts to resolve the dynamics of the host-parasite interaction with much higher accuracy in a host and in a nonhost inoculated with basidiospores of the cowpea rust fungus.

\section{Materials and methods}

\section{Plants}

Cowpea, Vigna sinensis L. cultivar California Blackeye, was obtained from W. Atlee Burpee Co., (Warminster, PA) and broad bean, Vicia faba cultivar Hedosa from RijksZwaan (Holland). Plants were grown at $20 \pm 2^{\circ} \mathrm{C}$ and illuminated for a 16-h photoperiod with $11000 \mathrm{~lx}$. Expanded primary leaves of 14-day-old plants were used for the experiments.

\section{Fungus}

The cowpea rust fungus, Uromyces vignae Barclay, race CPR-1, was obtained from Dr. M. C. Heath, Toronto, Ont. Basidiospores 


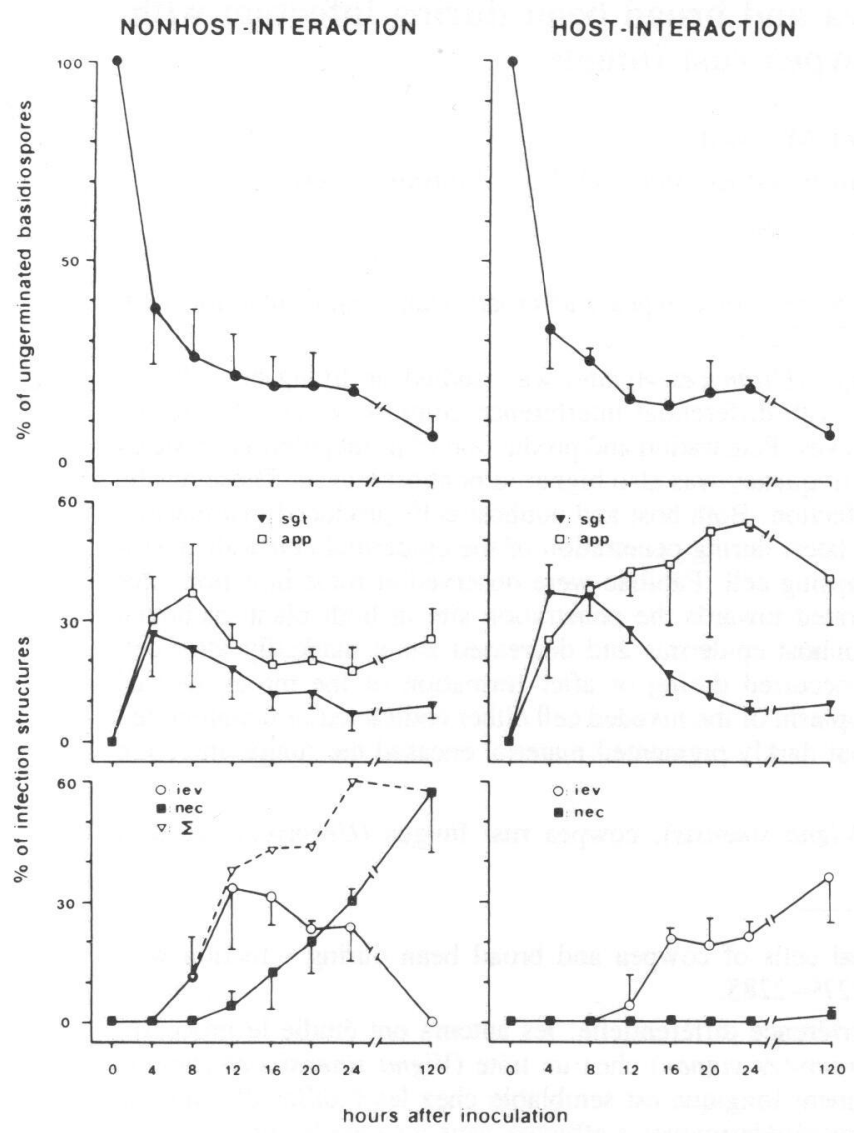

Abbreviations: A, apiculus; Ag, cytoplasmic aggregate; Ap, appressorium; app, basidiospores with germ tubes and appresoria; $\mathrm{CW}$, plant cell wall; $\mathrm{Gt}$, germ tube; $\mathrm{H}$, hypha; IEV, intraepidermal vesicle; iev, basidiospores that produced IEVs in living epidermal cells; N, nucleus; nec, basidiospores that produced IEVs within necrotic cells, $\mathrm{P}$, penetration peg; $\mathrm{Pa}$, papilla; $\mathrm{Ph}$, primary hyphae; $\mathrm{Pl}$, plasmalemma; S, basidiospore; Se, septum; sgt, basidiospores with short germ tubes; V, vacuole; $\Sigma$, integrated amounts of iev and nec.

FIG. 1. Differentiation of the basidiospores of the cowpea rust fungus on the host cowpea cv. California Blackeye and on the nonhost broad bean cv. Hedosa.

were obtained from teliospores stored in the dark. They were suspended in sterile water and brushed on wet filter paper supported on $2 \%$ water agar in a Petri dish. After incubation at $18 \pm 1{ }^{\circ} \mathrm{C}$ and $100 \%$ relative humidity $(\mathrm{RH})$ for $72 \mathrm{~h}$ in the dark, spores were illuminated for $8-10 \mathrm{~h}$ with $11000 \mathrm{~lx}$ fluorescent light. During this illumination, the germinating teliospores produced basidiospores that did not germinate immediately.

\section{Inoculation}

Expanded primary leaves of Vigna sinensis and Vicia faba were removed and vacuum-infiltrated with tap water for 2-5 min. The leaves were removed from the water and remaining water droplets were wiped off with filter paper. The Petri dish with the basidiospores was turned upside down and placed over the leaf at 100\% RH. The basidiospores were allowed to settle on the leaf for $1 \mathrm{~h}$. Subsequently, the Petri dish was removed and the inoculated leaf was kept at room temperature and high humidity conditions until observation.

\section{Microscopy}

The inoculated leaf was cut into pieces of $1 \times 1.5 \mathrm{~cm}$. To improve image quality, leaf pieces from the nonhost were mounted in tap water or in immersion oil (518 Carl Zeiss, Germany) and the leaf pieces from the host in immersion oil. This treatment restricted the time of observation to $3 \mathrm{~h}$ with tap water and to $2 \mathrm{~h}$ with oil. A Zeiss standard microscope, equipped with differential interference contrast (DIC) optics, was used.

For video-enhanced microscopy, a Reichert-Jung Polyvar microscope equipped with DIC was used. The camera equipment was from Hamamatsu Photomics, the recorder from Panasonic (time lapse cassette recorder), and the video tape from Fuji (Super XG pro E-180). Photographs were taken with Agfa ortho 25 professional film.

\section{Results}

\section{Fungal development on host and nonhost plants}

Fungal development was studied at 4-h intervals until $24 \mathrm{~h}$ after inoculation and again at $120 \mathrm{~h}$. Fungal development was classified into six stages at each time of observation: ( $i$ ) ungerminated basidiospores; (ii) basidiospores with short germ tubes (less than twice the length of the spore); (iii) basidiospores with long germ tubes (greater than twice the length of the spore); (iv) basidiospores with germ tubes and appressoria; (v) basidiospores that produced intraepidermal vesicles (IEV) in living epidermal cells; ( $v i$ ) basidiospores that produced IEVs within necrotic cells. At each time of observation at least 400 spores or infection structures from at least eight leaves were counted. The results are summarized in Fig. 1. The data of the basidiospores with long germ tubes, representing less than $5 \%$ of all inoculated basidiospores, are not included in Fig. 1 because they neither developed further infection structures nor penetrated the plants.

During the first $8 \mathrm{~h}$, basidiospores developed similarly and produced appressoria on both host and nonhost plants. Subsequently, fungal development on host plants seemed to halt, whereas on nonhost plants the fungus started to penetrate epidermal cells immediately and produced intraepidermal vesicles about $4 \mathrm{~h}$ earlier than on host plants. At the end of the experiment ( $120 \mathrm{~h}$ p.i.), $57 \%$ of all basidiospores had penetrated into the nonhost epidermis, but only $37 \%$ had penetrated the host epidermis. Therefore, the penetration efficiency of the basidiospores on the nonhost plant was higher than on the host plant.

\section{Cytology of basidiospore infection structures}

Most basidiospores produced single short germ tubes that started to emerge $2 \mathrm{~h}$ after inoculation. Sometimes an additional short germ tube was observed close to the apiculus (Fig. 2). However, this second germ tube never developed any infection structures. Most germ tubes swelled slightly at their tip to produce appressoria (Fig. 2) at about 2-6 h p.i. A penetration peg was formed below these appressoria, with a diameter of approximately $1 \mu \mathrm{m}$. In a few cases penetration occurred without swelling of the hyphal tips (Fig. 3).

The penetration peg extended to form the IEV at $10-16 \mathrm{~h}$ p.i. (Fig. 4). Most fungal cytoplasm migrated into this structure, leaving large vacuoles in the basidiospore (Figs. 2, 3). The IEV elongated, leaving a large vacuole in the proximal part (Fig. 4). A septum developed at the distal end of the IEV. The hypha subsequently branched and penetrated into neighbouring cells (Figs. 5, 7). Only a few vacuoles were observed in these primary hyphae (Fig. 7). Further growth of hyphae in the mesophyll tissue was observed only after clearing and staining with diethanol (Kuck et al. 1981) (Fig. 6). At $120 \mathrm{~h}$ p.i., fungal colonies had a diameter of $0.15 \mathrm{~mm}$ in the host plant. In the nonhost plant, fungal growth stopped after formation of the IEV, and very few septa were observed. 


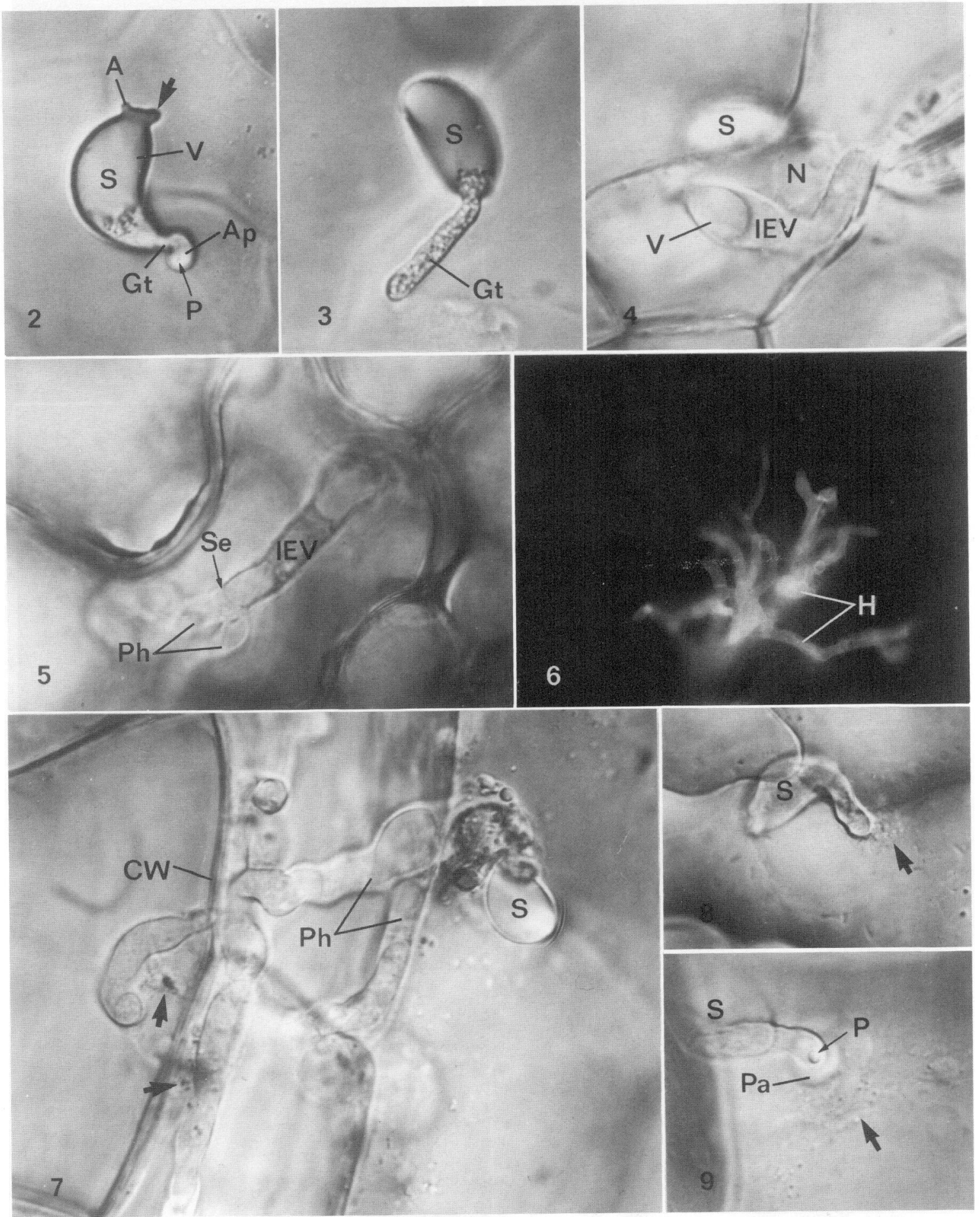

FIGS. 2-9. Development of basidiospores on Vigna sinensis leaves. Fig. 2. (16 h p.i.) Basidiospore with germ tube, appressorium, and penetration peg $1 \mu \mathrm{m}$ in diameter below the appressorium. Most of spore cytoplasm has migrated into the IEV. The additional short germ tube (arrow) close to the apiculus did not develop further. $\times 1187$. Fig. 3 . (16 h p.i.) Basidiospore without evidence of appressorium. $\times 1187$. Fig. 4. (24 h p.i.) Elongated IEV with large vacuole in the proximal end. The plant cell nucleus is close to the distal end of the IEV. $\times 1187$. Fig. 5. (48 h p.i.) After formation of a septum, primary hyphae branch and ramify from the IEV. $\times 1075$. Fig. 6 . (120 h p.i.) Fluorescence microscopy of cleared and stained tissue shows branching of the fungal hyphae in the mesophyll. $\times 400$. Fig. 7. (120 h p.i.) Fungal colonization of neighbouring epidermal cells. Vacuoles were common in the IEV but rare in primary hyphae. Cytoplasmic aggregates (arrows) are visible around hyphae. $\times 1000$. Fig. 8 . (4 h p.i.) The cytoplasmic aggregate (arrow) below the fungal tip. $\times 1000$. Fig. 9 . (12 h p.i.) Penetration peg and a papilla under the appressorium surrounded by a cytoplasmic aggregate (arrow). $\times 1378$. 

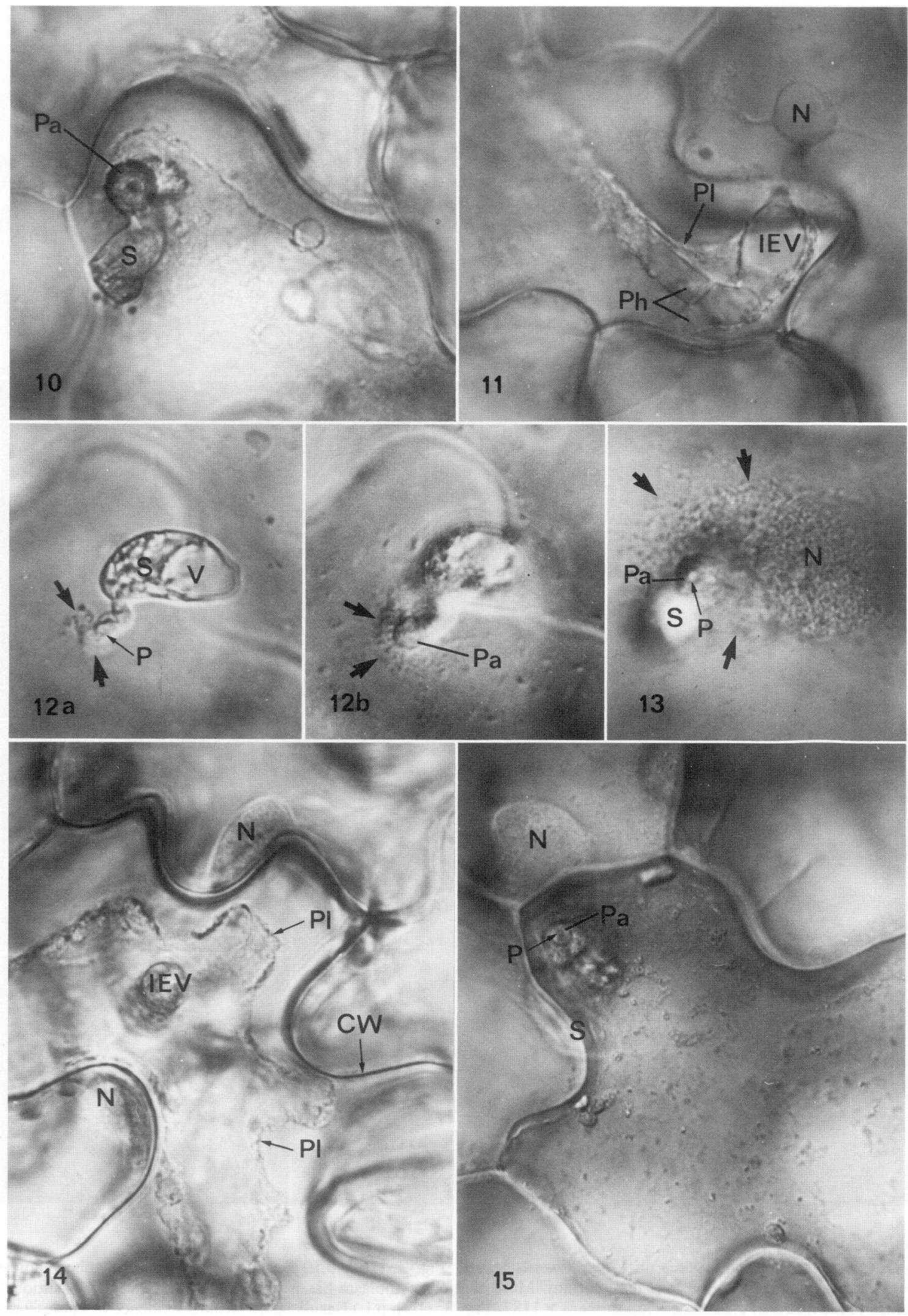

FIG. 10. (24 h p.i.) Collapsed host cell after infection. Fungal growth stopped in the collapsed cell. $\times 1000$. FIG. 11 . (120 h p.i.) Although the fungus had produced a colony $0.15 \mathrm{~mm}$ in diameter, only the first invaded cell had collapsed. Fungal structures in the collapsed cell remained intact. $\times 1000$. Figs. 12-15. Infection of Vicia faba leaves. Fig. 12. (6 h p.i.) (a) Plane of focus on basidiospore, penetration peg, vacuole in basidiospore and cytoplasmic aggregate (arrows). (b) The same site but with deeper focusing on the papilla and cytoplasmic aggregate (arrows). $\times 1187$. Fig. 13. ( $8 \mathrm{~h}$ p.i.) Large cytoplasmic aggregate (arrows) at the penetration site. Penetration peg and papilla are visible. The nucleus is also near the penetration site. $\times 1187$. Fig. 14 . ( $24 \mathrm{~h}$ p.i.) Collapsed nonhost cell showing cytoplasm contracted away from the cell wall. The nuclei of the neighbouring cells migrated towards the necrotic cell. $\times 1000$. Fig. 15 . (24 h p.i.) Collapsed nonhost cell without signs of contraction, but the cytoplasm is granulated. $\times 1125$. 

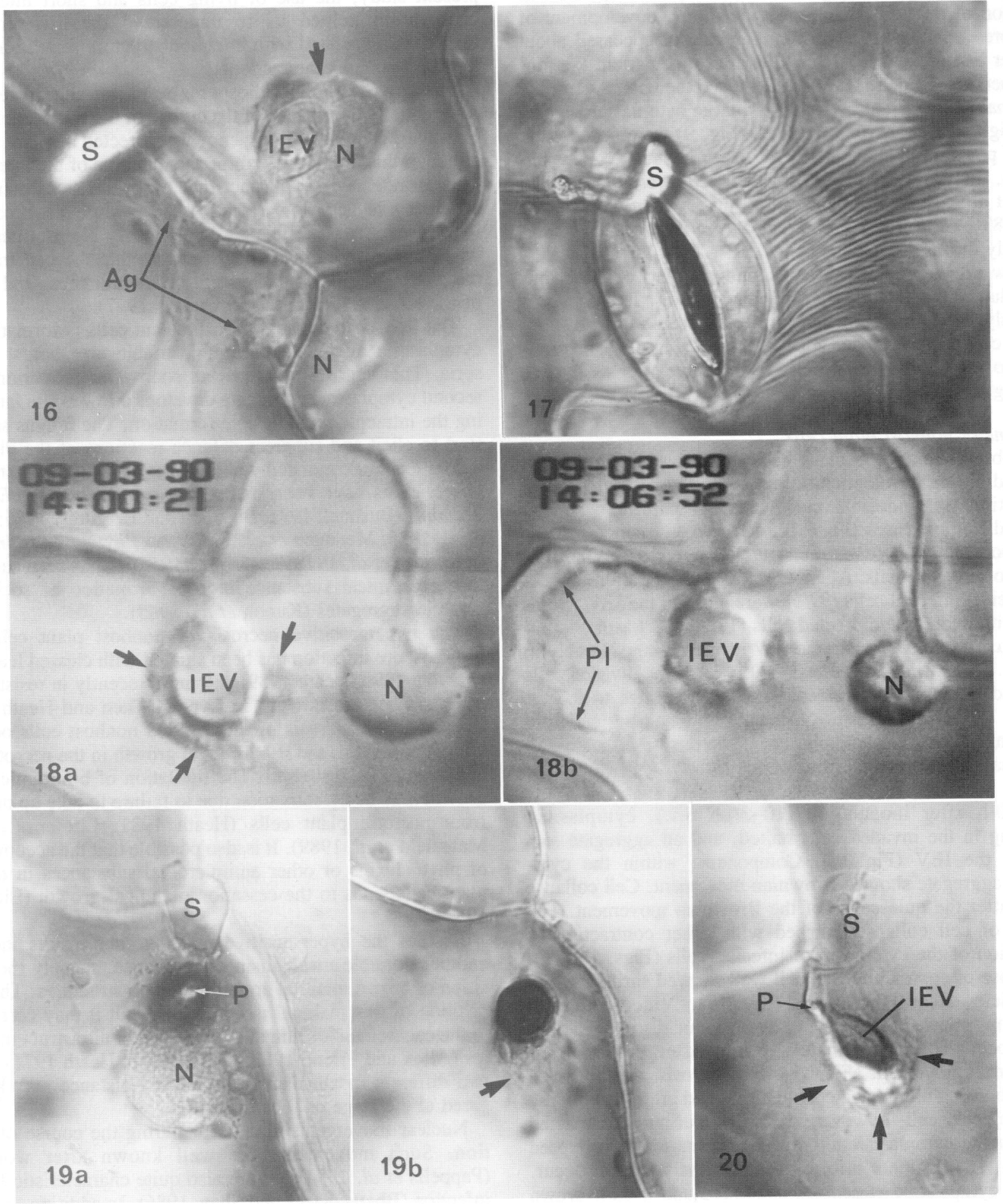

FIGS. 16-20. Infection of Vicia faba. Fig. 16. (16 h p.i.) Cytoplasmic aggregate (arrow) around the IEV after the halt in cytoplasmic streaming. There is also a cytoplasmic aggregate in the neighbouring cell. $\times 1187$. Fig. 17 . $(24 \mathrm{~h}$ p.i. $)$ Wrinkled cuticle after cell collapse. $\times 725$. Fig. 18. (12 h p.i.) Video-enhanced microscopy of cell collapse. Two frames in a sequence of about 6 mins. (a) Cytoplasmic aggregate (arrows) around the IEV. The nucleus is visible. (b) The same site, plasmalemma contracted away from cell wall. Note the change in size of the plant nucleus in $a$ and $b$. Fig. 19. (24 h p.i.) A dark brown area around the penetration peg. ( $a$ ) Plane of focus on a collapsed basidiospore and penetration peg. The nucleus close to the dark pigmented zone is visible in the living cell. $(b)$ The same site, at a lower plane of focus, shows the dark brown area deeper in the plant cell. Note cytoplasmic aggregate (arrow) near the dark brown area. $\times 1000$. Fig. 20 . $(24 \mathrm{~h}$ p.i.) Collapsed, dark pigmented IEV in living plant cell. Around the collapsed IEV the cytoplasmic aggregate (arrows) is visible. $\times 1225$. 
Reaction of host plant cells

There was no visible change in the epidermal cells underneath germinating basidiospores. The first plant response was formation of a cytoplasmic aggregate during development of the appressorium (Fig. 8). This aggregate disappeared about $1 \mathrm{~h}$ later in most cases. At 10-12 $\mathrm{h}$ after inoculation, the fungus penetrated epidermal cells and formed the IEV. Again, the epidermal cells reacted by forming a large cytoplasmic aggregate (Fig. 9). At this time, papillae (Fig. 9) were observed at $73 \%$ of penetration sites. At $14 \mathrm{~h}$ p.i., or about $2 \mathrm{~h}$ after penetration, the nuclei in $30 \%$ of invaded cells were close to the IEV. At about $4 \mathrm{~h}$ after penetration, nuclei were close to the IEV in $83 \%$ of invaded cells. Nuclear size did not change significantly during infection.

A few infected epidermal cells showed signs of disorganisation during the 1st day after inoculation (Fig. 10). At $120 \mathrm{~h}$ p.i., only $1-2 \%$ of the primary infected cells were necrotic. In such cells fungal hyphae appeared intact (Fig. 11) and ramified into the neighbouring cells in the same way as hyphae infecting living cells.

\section{Reactions of nonhost plant cells}

As observed in host plant cells, cytoplasmic aggregates appeared during development of appressoria and again during penetration of epidermal cell walls. A papilla was also observed in most cases (Figs. 12, 13).

At about $2 \mathrm{~h}$ after penetration, nuclei were close to the IEV in $78 \%$ of infected cells. At about $4 \mathrm{~h}$ after penetration, almost all nuclei of infected cells (97\%) were close to the IEV. Compared with nuclei in uninfected cells $(17.2 \pm 2.1 \mu \mathrm{m} \times 12.4$ $\pm 2.9 \mu \mathrm{m})$, nuclei close to the IEV increased considerably in size $(19.1 \pm 2.8 \mu \mathrm{m} \times 14.6 \pm 2.9 \mu \mathrm{m})$. If the invaded cells collapsed, their nuclei decreased markedly in size to $8.7 \pm$ $2.2 \mu \mathrm{m} \times 7.0 \pm 1.0 \mu \mathrm{m}$. Nuclei in neighbouring cells did not change their size but migrated towards the infected cell and remained close to the wall of the infected cell (Figs. 14, 15).

At $20 \mathrm{~h}$ after inoculation (10-30 h p.i.), cytoplasmic streaming in the invaded cells halted, and an aggregate surrounded the IEV (Fig. 16). Components within the cytoplasmic aggregate showed Brownian movement. Cell collapse started after the quiescence of the Brownian movement. The process of cell collapse finished with either contraction or granulation of the cytoplasm of infected cells (Figs. 14, 15). In the case of contraction, the cell wall showed shrinkage and the cuticle became wrinkled (Fig. 17). Video-enhanced microscopy showed the course of cytoplasmic disorganisation, which occurred approximately $6 \mathrm{~min}$ after cessation of cytoplasmic movement (Fig. 18). No necrosis was observed in neighbouring uninfected cells. During and after the collapse of the infected cell, however, the neighbouring cells reacted by producing cytoplasmic aggregate adjacent to the collapsed cell (Fig. 16). In other infected cells necrosis did not occur. Instead, cytoplasmic streaming continued and a dark brown material completely surrounded the IEV (Figs. 19-20). Cells showing necrosis or the dark brown material were observed at a ratio of $7: 3$ at $36 \mathrm{~h} \mathrm{p.i.}$

\section{Discussion}

The development and cytology of basidiospore infection structures were very similar to those observed in cleared tissue of infected cowpea (Heath 1989). Also, infection structures induced on artificial membranes were quite similar to those observed in the leaf (Freytag et al. 1988). However, in the present study, the use of living cells and short intervals of observation helped us to understand the different plant responses associated with infection structure formation during host and nonhost interactions.

The cowpea rust basidiospores were not able to recognize differentially the surface of the cuticle of the two plant species. However, penetration efficiency was affected by plant species, although this did not determine the outcome of the interaction. This is indicated by the fact that on bean leaves penetration efficiency is very low (Heath 1989), while on broad bean leaves penetration efficiency is obviously higher than on the host plant cowpea. This may indicate that the penetration of the plant epidermis is dependent on the thickness and rigidity of the cuticle (Melander and Craigie 1927).

The first visible reaction of the plant cells is formation of a cytoplasmic aggregate of quite variable size below appressoria. This aggregate disappears soon after formation, but a second cytoplasmic aggregate develops a few hours later, during the intraepidermal vesicle formation. The fungus seems to start to elicit and suppress defence reactions of the plant cell before the epidermal cell wall is penetrated. Somewhat similar observations have been made during infections by Erysiphe graminis (Bushnell 1971; Bushnell and Bergquist 1975; Kunoh et al. 1985; Mendgen et al. 1987) and Phytophthora infestans (Kitazawa et al. 1973, Tomiyama 1956). It has been suggested that a chemical substance induces formation of such cytoplasmic aggregates (Kunoh et al. 1985).

The hypersensitive necrosis of nonhost plant cells after basidiospore infection has been studied with cleared leaf tissue (Freytag 1990; Heath 1989) and more recently in resistant living plant cells of cowpea leaf veins (Chen and Heath 1991). Rapid limited necrosis of the invaded nonhost cells occurred after formation of the IEV. Fungal growth in the necrotic cells appeared to be restricted. The limitation of biotrophic fungal growth may be by starvation due to failure to take up nutrients from necrotic plant cells (Heath 1981; Liu et al., 1989; Mansfield et al. 1989). It is also possible that the accumulation of phytoalexins or other antimicrobial substances in necrotic plant cells leads to the cessation of fungal growth (Liu et al. 1989).

Besides the hypersensitive reaction, our results indicated another possible mechanism of resistance, namely the deposition of brown material around infection structures. The composition of this material is not known, but it may correspond to the encasement of fungal growth seen in ultrastructural studies (Allen and Friend 1983; Coffey 1976; Heath 1971). These two different mechanisms of nonhost resistance may be triggered at the stage of IEV formation.

Nuclear movements also occur during the course of infection. Such movements are well known after wounding (Pappelis et al. 1974) but are also quite characteristic for rust infection (Bhattacharya and Shaw 1986). In addition, in resistant combinations nuclear migration to the infection site seems to be faster (Pappelis et al. 1974) or the migration forces more induced (Tomiyama 1956). Changes in nuclear size during infection have been reported for other host-parasite combinations (Bhattacharya and Shaw 1986; Contreras and Boothroyd 1975; Kulfinski and Pappelis 1971). The increase of nuclear size and high speed of cytoplasmic streaming $(\mathrm{H} . \mathrm{Xu}$, unpublished data) might reflect extremely high metabolic activity in an infected cell. 
These findings indicate that the hypersensitive cell death associated with nonhost resistance of Vicia faba involves a sequence of different cytological events.

\section{Acknowledgements}

We thank Dr. U. Wyss for the use of the video-enhanced microscope and Dr. R. J. O'Connell and Dr. G. T. N. De Leeuw for critical reading of the manuscript. H. Xu gratefully acknowledges the Government of Shanxi Province, People's Republic of China and the Deutscher Akademischer Austauschdienst for student fellowships.

Allen, F. H. E., and Friend, J. 1983. Resistance of potato tubers to infection by Phytophthora infestans: a structural study of haustorial encasement. Physiol. Plant Pathol. 22: 285-292.

Bhattacharya, P. K., and Shaw, M. 1968. The effect of rust infection on DNA, RNA, and protein in nuclei of Khapli wheat leaves. Can. J. Bot. 46: 96-99.

Bushnell, W. R. 1971. The haustorium of Erysiphe graminis. An experimental study by light microscopy. In Morphological and biochemical events in plant-parasite interaction. Edited by S. Akai and S. Ouchi. The Phytopathology Society of Japan, Tokyo pp. 229-254.

Bushnell, W. R., and Bergquist, S. E. 1975. Aggregation of host cytoplasm and the formation of papillae and haustoria in powdery mildew of barley. Phytopathology, 65: 310-318.

Chen, C. Y., and Heath, M. C. 1991. Cytological studies of the hypersensitive death of cowpea epidermal cells induced by basidiospore-derived infection by the cowpea rust fungus. Can. J. Bot. 69: 1199-1206.

Coffey, M. D. 1976. Flax rust resistance involving the K gene: an ultrastructural survey. Can. J. Bot. 54: 1443-1457.

Contreras, M. R., and Boothroyd, C. W. 1975. Histological reactions and effects on position of epidermal nuclei in susceptible and resistant corn inoculated with Helminthosporium maydis race T. Phytopathology, 65: 1075-1078.

FREYTAG, S. 1990. Oberflächenkohlenhydrate und Zellwandaufbau von in vitro-induzierten Infektionsstrukturen von Rostarten. Dissertation, Universität Konstanz, Germany.

Freytag, S., Bruscaglioni, L., Gold, R. E., and Mendgen, K. 1988. Basidiospores of rust fungi (Uromyces species) differentiate infection structures in vitro. Exp. Mycol. 12: 275-283.

Gold, R. E., and MendGen, K. 1984. Cytology of basidiospore germination, penetration, and early colonization of Phaseolus vulgaris by Uromyces appendiculatus var. appendiculatus. Can. J. Bot. 62: 1989-2002.

1991. Rust basidiospore germlings and disease initiation. In The fungal spore and disease initiation in plant and animals.
Edited by G. T. Cole and H. C. Hoch. Plenum Press, New York. pp. 67-99.

Heath, M. C. 1971. Haustorial sheath formation in cowpea leaves immune to rust infection. Phytopathology, 61: 383-388.

- 1981. Nonhost resistance. In Plant disease control. Resistance and susceptibility. Edited by R. C. Staples and G. H. Toenniessen. John Wiley \& Sons, New York. pp. 200-217.

1989. A comparison of fungal growth and plant responses in cowpea and bean cultivars inoculated with urediospores or basidiospores of the cowpea rust fungus. Physiol. Mol. Plant Pathol. 34: 415-426.

Kitazawa, K., Inagaki, H., and Tomiyama, K. 1973. Cinephotomicrographic observations on the dynamic responses of protoplasm of a potato plant cell to infection by Phytophthora infestans. Phytopathol. Z. 76: 80-86.

Kuck, K. H., Tiburzy, R., Hänssler, G., and Reisener, H.-J. 1981. Visualization of rust hautoria in wheat leaves by using fluorochromes. Physiol. Plant Pathol. 19: 439-441.

Kulfinski, F. B., and Pappelis, A. J. 1971. Interference microscopy of onion epidermal nuclei in response to three fungal pathogens. Physiol. Plant Pathol. 1: 489-494.

Kunoh, H., Aist, J. R., and Hayashimoto, A. 1985. The occurrence of cytoplasmic aggregates induced by Erysiphe pisi in barley coleoptile cells before the host cell walls are penetrated. Physiol. Plant Pathol. 26: 199-207.

LiU, Q., Rimmer, S. R., and ScArth, S. 1989. Histopathology of compatibility and incompatibility between oilseed rape and Albugo candida. Plant Pathol. 38: 176-182.

Mansfield, J. W., Woods, A. M., FagG, J., and Bennett, M. 1989. Control of hypersensitive reaction of lettuce to the downy mildew fungus Bremia lactucae. In Signal molecules in plantmicrobe interactions. Edited by B. J. J. Lugtenberg. SpringerVerlag, Berlin. pp. 251-260.

Melander, L. W., and Craigie, J. H. 1927. Nature of resistance of Berberis sp. to Puccinia graminis. Phytopathology, 17(2): 95114.

Mendgen, K., Keller, G., and Kuhn, C. 1987. Infektion und Wirtsreaktion beim Gerstenmehltau. Film C1642 des Institut für Wissenschaftlichen Film, Göttingen, Nonnensteig. Publication von K. Mendgen. Publ. Wiss. Film., Sekt. Biol., Ser. 19, Nr. 19/C1642/ 1987, 1-19.

Pappelis, A. J., Pappelis, G. A., and Kulfinski, F. B. 1974. Nuclear orientation in onion epidermal cells in relation to wounding or infection. Phytopathology, 64: 1010-1012.

TomiYAma, K. 1956. Cell physiological studies on the resistance of potato plant to Phytophthora infestans. IV. On the movements of cytoplasm of the host cell induced by the invasion of Phytophthora infestans. Ann. Phytopathol. Soc. Jpn. 21: 54-62. 